\title{
Epidemiology and the Risk Factors for Mortality in Ventilator-Associated Pneumonia
}

\section{Ventilatör ile ilişkili Pnömonide Epidemiyoloji ve Mortalite ile ilişkili Risk Faktörleri}

\author{
Zuhal Yesilbag ${ }^{1} \oplus$, Yasemin Tekdos Seker $^{2} \odot$ \\ ${ }^{1}$ Department of Infectious Diseases and Clinical Microbiology, Health Science University, Bakirkoy Dr. Sadi Konuk Education and Research \\ Hospital, Istanbul, Turkey \\ ${ }^{2}$ Department of Anesthesiology and Reanimation, Health Science University, Bakirkoy Dr. Sadi Konuk Education and Research Hospital, \\ Istanbul, Turkey
}

Received: 01.09.2020 / Accepted: 16.09.2020 / Published Online: 30.09.2020

Cite as: Yesilbag Z, Tekdos Seker Y. Epidemiology and the risk factors for mortality in ventilator-associated pneumonia. Med J Bakirkoy 2020;16(3):309-16.

\begin{abstract}
Objective: Ventilator-associated pneumonia (VAP) is the most common hospital-aquired infections in intensive care units (ICUs) and associated with prolonged hospital stay, increased mortality and cost. This study aims to analyse the epidemiology and the risk factors affecting 30 day-mortality in VAP.

Method: Adult patients with VAP were included in the study. Data were obtained from infection control commitee records. Patients were followed up for mortality until 30 days after onset of VAP or until death for the patients died within 30 days. Survivor and non-survivor groups were compared as for the predictors of mortality.

Results: A total of 183 VAP patients were evaluated. Early-onset VAP was observed in 16 (8.7\%), and late-onset VAP in 167 (91.3\%) patients. Acinetobacter baumannii was the most common cause of VAP (49.2\%), followed by Pseudomonas aeruginosa (19.7\%) and Klebsiella pneumoniae (13.7\%). Carbapenem resistance was seen in 78 (42.6\%) patients and among them, most frequently Acinetobacter baumannii $(62.8 \%, 49 / 78)$, followed by Klebsiella pneumoniae (20.5\%, 16/78), Pseudomonas aeruginosa $(14.1 \%, 11 / 78)$ and Escherichia coli $(2.6 \%$, $2 / 78)$ were isolated. Thirty day-mortality rate was $46.4 \%(n=85)$. In univariate analysis; malignity, blood transfusion, renal replacement therapy, Higher APACHE II, SOFA and SAPS 2 scores on the day of VAP onset and Acinetobacter baumannii were found to be more common in nonsurvivor group. According to the Cox-regression analysis, only SOFA score on the day of VAP onset and Acinetobacter baumannii were independent predictors of mortality. Although rate of trauma patients was significantly higher in survivor group, in multivariate analysis it was not a protective factor for mortality.

Conclusion: The most common cause of VAP was Acinetobacter baumannii and carbapenem resistance was seen in more than half of Acinetobacter baumannii and Klebsiella pneumoniae isolates. Higher SOFA score on the day of VAP onset and Acinetobacter baumannii infections were found to be independently associated with 30-day mortality in VAP patients.
\end{abstract}

Keywords: ventilator-asociated pneumonia, mortality, SOFA score, Acinetobacter baumannii

öz

Amaç: Ventilatörle ilişkili pnömoni (ViP), yoğun bakım üniteleri (YBÜ)'de en sık hastane kaynaklı infeksiyonlardan biridir ve uzun süreli hastane yatışı, artan ölüm oranı ve maliyet ile ilişkilidir. Bu çalışma, YBÜ'de ViP tanılı hastalarda epidemiyoloji ve 30 günlük mortaliteyi etkileyen risk faktörlerini irdelemeyi amaçlamaktadır.

Yöntem: Erişkin ViP hastaları çalışmaya dahil edildi. Hasta verileri enfeksiyon kontrol komitesi kayıtlarından elde edildi. Hastalar ViP başlangıcından 30 gün sonrasına kadar veya 30 gün içinde öldüyse ölene kadar mortalite açııından takip edildi. Yaşayan ve ölen hastalar risk faktöreri açısından karşılaştıııldı.

Bulgular: Çalışmaya toplam 183 ViP hastası dahil edildi. Erken başlangıçı ViP $16(\% 8,7)$ hastada, geç başlangıçı ViP 167 (\%91,3) hastada görüldü. En sık ViP etkeni Acinetobacter baumannii idi $(\% 49,2)$, bunu Pseudomonas aeruginosa $(\% 19,7)$ ve Klebsiella pneumoniae $(\% 13,7)$ izledi. 78 (\%42.6) hastada karbapeneme direnç görüldü. Bu hastalarda sıklık sırasına göre Acinetobacter baumannii (\% 62.8, 49/78), Klebsiella pneumoniae $(\% 20.5,16 / 78)$, Pseudomonas aeruginosa (\%14.1, 11/78) ve Escherichia coli (\%2.6, 2/78) izole edildi. Çalışmada otuz günlük mortalite oranı \%46,4 ( $n=85)$ olarak bulundu. Tek değişkenli analizde; ölen grupta malignite, kan transfüzyonu, renal replasman tedavisi, APACHE II, SOFA ve SAPS II skorları ve Acinetobacter baumannii sıklığının daha fazla olduğu görüldü. Cox-regresyon analizine göre, sadece ViP geliştiği andaki SOFA skoru ve Acinetobacter baumannii mortalitenin için bağımsız risk faktörü olarak bulundu. Yaşayan grupta travma hastalarının oranı anlamlı olarak daha yüksek olmasına rağmen, travma çok değişkenli analizde mortalite için koruyucu bir faktör değildi.

Sonuç: ViP hastalarında en sık etken Acinetobacter baumannii idi ve karbapenem direnci Acinetobacter baumannii ve Klebsiella pneumoniae izolatlarının yarısından fazlasında görüldü.VIP gelişstiği andaki SOFA skoru yüksekliği ve Acinetobacter baumannii infeksiyonu VIP hastalarında 30 günlük mortalite ile bağımsız olarak ilișkili bulundu.

Anahtar kelimeler: ventilatörle ilişkili pnömoni, mortalite, SOFA skoru, Acinetobacter baumannii

Corresponding Author:

zuhalyes@gmail.com
Z. Yesilbag 0000-0002-7210-1084

Y. Tekdos Seker 0000-0001-6924-9814

(C) Telif hakkı Sağlık Bilimleri Üniversitesi Bakırköy Dr. Sadi Konuk Eğitim ve Araştırma Hastanesi'ne aittir. Logos Tıp Yayıncılık tarafından yayınlanmaktadır. Bu dergide yayınlanan bütün makaleler Creative Commons Atff-GayriTicari 4.0 Uluslararası Lisansı ile lisanslanmıştır.

(c) Copyright Health Sciences University Bakırköy Sadi Konuk Training and Research Hospital. This journal published by Logos Medical Publishing.

Licenced by Creative Commons Attribution-NonCommercial 4.0 International (CC BY) 


\section{INTRODUCTION}

Ventilator-associated pneumonia (VAP) is defined as the pneumonia developed more than 48 hours after intubation in patients on mechanical ventilation. It is one of the most common hospital-aquired infections in intensive care units (ICUs) and associated with prolonged duration of hospital stay, increased mortality rate and cost ${ }^{(1-4)}$.

VAP develops in approximately $10-40 \%$ of patients on mechanical ventilation, with large variations among ICUs. Mortality rates due to VAP has been reported varying from $20 \%$ to $50 \%$ in the literature ${ }^{(5-8)}$. Prior studies have identified the risk factors that affect the prognosis of VAP ${ }^{(9-11)}$. Multidrug-resistant (MDR) microorganisms, the severity of illness, and inadequate initial antibiotic therapy have been identified as determinants of ICU mortality in patients with VAP. Underlying diseases such as chronic obstructive pulmonary disease (COPD) are also believed to effect the mortality in VAP patients ${ }^{(12)}$. This study aims to analyse the epidemiology of VAP and identify the risk factors affecting 30 day-mortality of the patients with VAP in a tertiary care hospital ICU.

\section{MATERIALS and METHODS}

This retrospective study was conducted in a 612-bed tertiary care hospital which has a 31-bed Anesthesiology and Reanimation ICU, nine-bed neurology ICU, 16-bed coronary ICU, seven-bed cardiovasculary ICU, 26-bed neonatal ICU and a 16-bed pediatric ICU. We performed the study in Anesthesiology and Reanimation ICU which accepts patients from both medical and surgical wards. The study was approved by the Ethics Committee.

Adult patients with VAP ( $\geq 18$ years) who were hospitalized in ICU between January 2016 and January 2019 were included in the study. VAP is defined as a new or progressive pulmonary infiltration occurring more than $48 \mathrm{~h}$ after intubation in combination with at least 2 of the following criteria: temperature $>38.5^{\circ} \mathrm{C}$ or $<36.5^{\circ} \mathrm{C}$; change in character of sputum (purulent or increased amount of sputum); white blood cell count $>10000$ cells $/ \mathrm{mm}^{3}$ or $<4000$ cells/ $\mathrm{mm}^{3}{ }^{(13)}$. VAP is classified as early-onset VAP, occurring within 4 days of intubation, and late-onset VAP, occuring on the fifth day or later, after intubation. Respiratory samples were obtained from either endotracheal aspirate (ETA) or bronchoalveolar lavage (BAL) to determine the causative microorganism and quantitative culture cut-off points of $>10^{6}$ $\mathrm{CFU} / \mathrm{ml}$ and $>10^{4} \mathrm{CFU} / \mathrm{ml}$ were used respectively. In cases with recurrent VAP, only the first episode was included in the study. The patients who had pneumonia at admission, multiple microorganisms in the ETA culture or the patients who did not meet the VAP criteria despite the growth of microorganisms in the ETA culture were excluded from the study. Data about demographic characteristics, underlying diseases, length of ICU stay, invasive procedures, duration of mechanical ventilation prior to VAP, and causative microorganisms were retrieved from the infection control commitee records. Acute Physiology and Chronic Health Evaluation (APACHE) II score, Sequential Organ Failure Assessment (SOFA) score and Simplified Acute Physiology Score (SAPS II) were recorded both on the admission day and the day of VAP onset. Patients were followed up for mortality until 30 days after onset of VAP or until death for the patients died within 30 days. Statistical analyses were performed by using the Statistical package for Social Sciences version 25.0 for Windows (SPSS Inc., Chicago, IL, USA). Descriptive data were presented as mean \pm standard deviation, frequency, median and percentage values. Categorical variables were compared using chi- square test and Fisher's Exact test. The normality of continuous variables was tested with the Kolmogorov- Smirnov test. Student's t-test was used for comparing the normally distributed continuous variables and, Mann-Whitney $U$ test for comparing the continuous variables which were not normally distributed. Cox regression analysis was used for multivariate analysis to evaluate the independent variables associated with 30 -day mortality. The " $p$ " values less than or equal to $0.05(p \leq 0.05)$ were considered as statistically significant.

\section{RESULTS}

A total of 183 VAP patients were enrolled in the study. Out of them, 116 (63.4\%) were male and 67 $(36.6 \%)$ were female with an overall mean age of $53.15 \pm 20.88$ years (min: 18 , max: 94). Early-onset VAP was observed in $16(8.7 \%)$ patients and lateonset VAP in 167 (91.3\%) patients. Acinetobacter 
Table 1. Mortality associated risk factors in ventilator-associated pneumonia.

\begin{tabular}{|c|c|c|c|c|c|}
\hline & $\begin{array}{l}\text { Survivor } \\
(n=98)\end{array}$ & $\begin{array}{c}\text { Non-survivor } \\
(n=85)\end{array}$ & $\mathbf{p}$ & OR & $95 \% \mathrm{Cl}$ \\
\hline \multicolumn{6}{|l|}{ Sex, n (\%) } \\
\hline Male & $67(68.4)$ & $49(57.6)$ & & & \\
\hline Female & 31 (31.6) & $36(42.4)$ & 0.13 & 1.63 & $0.34-1.15$ \\
\hline Age, year (mean $\pm s d)$ & $50.62 \pm 21.03$ & $56.14 \pm 20.42$ & 0.08 & & \\
\hline Hospitalization before ICU, n (\%) & $40(40.8)$ & $40(47.1)$ & 0.39 & 1.28 & $0.71-2.31$ \\
\hline Length of ICU stay, day, median (IQR) & $32(21-47)$ & $31(21-48)$ & 0.85 & & \\
\hline APACHE II on admission, median (IQR) & $20(15-25)$ & $20(15-26)$ & 0.18 & & \\
\hline SOFA on admission, median (IQR) & $8(5-10)$ & $9(6-11)$ & 0.06 & & \\
\hline SAPS II on admission, median (IQR) & $45(36-23)$ & $48(37-61)$ & 0.16 & & \\
\hline APACHE II on the day of VAP onset, median (IQR) & $18(12-23)$ & $24(19-28)$ & $<0.001^{*}$ & & \\
\hline SOFA on the day of VAP onset, median (IQR) & $4(3-7)$ & $10(6-3)$ & $<0.001^{*}$ & & \\
\hline SAPS II on the day of VAP onset, median (IQR) & $39(31-49)$ & $48(43-60)$ & $<0.001^{*}$ & & \\
\hline Duration of mechanical ventilation before VAP, day, median (IQR) & $11(7-19)$ & $11(7-18)$ & 0.94 & & \\
\hline \multicolumn{6}{|l|}{ Type of VAP, $n(\%)$} \\
\hline Early & $7(7.1)$ & $9(10.6)$ & & & \\
\hline Late & 91 (92.9) & $76(89.4)$ & 0.41 & 0.65 & $0.23-1.82$ \\
\hline Trauma, n (\%) & $34(34.7)$ & $15(17.6)$ & $0.009 *$ & 0.40 & $0.20-0.80$ \\
\hline Secondary BSI, n (\%) & $2(2)$ & $5(5.9)$ & 0.17 & 3 & $0.56-15.88$ \\
\hline Carbapenem resistance, $\mathrm{n}(\%)$ & $36(36.7)$ & $42(49.4)$ & 0.08 & 1.68 & 0.93-3.03 \\
\hline Colistin resistance, $\mathrm{n}(\%)$ & $1(1)$ & $3(3.5)$ & 0.33 & 3.5 & $0.36-34.77$ \\
\hline \multicolumn{6}{|l|}{ Underlying diseases, n (\%) } \\
\hline Hypertention & $24(24.5)$ & $25(29.4)$ & 0.45 & 1.28 & $0.66-2.47$ \\
\hline Heart failure & $6(6.1)$ & $9(10.6)$ & 0.27 & 1.81 & $0.61-5.33$ \\
\hline Diabetes mellitus & $13(13.3)$ & $14(16.5)$ & 0.54 & 1.28 & $0.56-2.92$ \\
\hline Chronic renal failure & $9(9.2)$ & $14(16.5)$ & 0.13 & 1.95 & $0.79-4.76$ \\
\hline Coronary artery disease & $11(11.2)$ & $7(8.2)$ & 0.49 & 0.71 & $0.26-1.92$ \\
\hline Malignity & $3(3.1)$ & $13(15.3)$ & $0.003^{*}$ & 5.71 & $1.57-20.81$ \\
\hline COPD & $8(8.2)$ & $5(5.9)$ & 0.54 & 0.70 & $0.22-2.23$ \\
\hline Neurological diseases & $7(7.1)$ & $4(4.7)$ & 0.48 & 0.64 & $0.18-2.27$ \\
\hline \multicolumn{6}{|l|}{ Invasive procedures, n (\%) } \\
\hline Tracheostomy & $75(76.5)$ & $60(70.6)$ & 0.36 & 0.73 & $0.38-1.42$ \\
\hline Blood transfusion & $74(75.5)$ & $78(91.8)$ & $0.003^{*}$ & 3.61 & $1.46-8.88$ \\
\hline CVC & $82(83.7)$ & $75(88.2)$ & 0.37 & 1.46 & $0.89-2.94$ \\
\hline Nazogastric tube & $97(99)$ & $85(100)$ & 1 & 1.87 & $1.63-2.15$ \\
\hline Total parenteral nutrition & $52(53.1)$ & $55(64.7)$ & 0.11 & 1.62 & $0.89-2.94$ \\
\hline Hemodialysis/CRRT & $26(26.5)$ & $51(60)$ & $<0.001^{*}$ & 4.1 & $2.22-7.75$ \\
\hline \multicolumn{6}{|l|}{ Microorganism, n (\%) } \\
\hline Klebsiella pneumoniae & $11(11.2)$ & $13(15.3)$ & 0.41 & 1.42 & $0.60-3.38$ \\
\hline Acinetobacter baumannii & $38(38.8)$ & $52(61.2)$ & $0.003^{*}$ & 2.48 & $1.37-4.51$ \\
\hline Pseudomonas aeruginosa & $24(24.5)$ & $12(14.1)$ & 0.07 & 0.5 & $0.23-1.08$ \\
\hline Staphylococcus aureus & $7(7.1)$ & $3(3.5)$ & 0.28 & 0.47 & $0.11-1.9$ \\
\hline
\end{tabular}

OR: Odd's ratio, sd: standard deviation, IQR: interquartile range VAP: ventilator-associated pneumonia, BSI: Bloodstream infection, CVC: Central venous catheter CRRT: continuous renal replacement therapy

baumannii was the leading cause of VAP (49.2\%), followed by Pseudomonas aeruginosa (19.7\%) and Klebsiella pneumoniae (13.7\%). The distribution of microorganisms that caused VAP was shown in Figure 1. Carbapenem resistance was seen in 78 $(42.6 \%)$ patients and among them, Acinetobacter baumannii (62.8\%, 49/78), Klebsiella pneumoniae (20.5\%, 16/78), Pseudomonas aeruginosa (14.1\%, $11 / 78)$ and Escherichia coli $(2.6 \%, 2 / 78)$ were isolated. The carbapenem resistance rates for each micro- organizm was shown in Figure 2. Colistin resistance was seen only in Klebsiella pneumoniae species in 4 (2.2\%) patients. Secondary bloodstream infections were seen in seven patients, four of them were infected with Acinetobacter baumannii, two of them with Klebsiella pneumoniae and one of them with S.aureus.

Thirty day-mortality rate was found to be $46.4 \%$ $(n=85)$ in the study. Survivor and non-survivor groups 


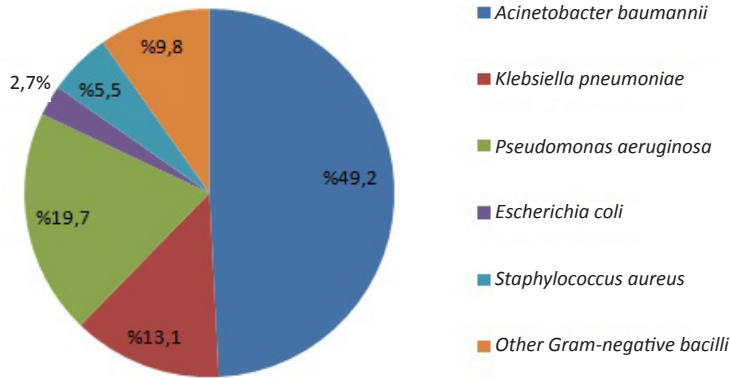

Figure 1. Distribution of bacteria that caused ventilatorassociated VAP

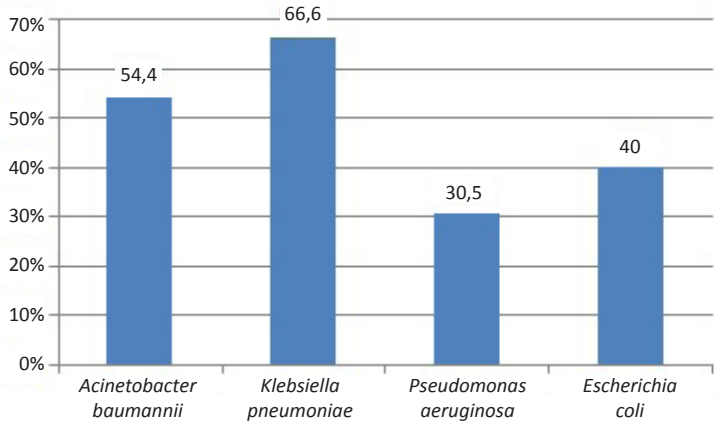

Figure 2. Carbapenem resistance rates for each bacteria.

Table 2. Cox regression analysis of risk factors for mortality in ventilator-associated pneumonia.

\begin{tabular}{|c|c|c|c|c|c|}
\hline & $\begin{array}{c}\text { Survivor } \\
(n=98)\end{array}$ & $\begin{array}{l}\text { Non-survivor } \\
\quad(n=85)\end{array}$ & $\mathbf{p}$ & OR & $\% 95 \mathrm{Cl}$ \\
\hline APACHE II on the day of VAP onset, median (IQR) & $18(12-23)$ & $24(19-28)$ & 0.11 & 1.03 & $0.99-1.07$ \\
\hline SOFA on the day of VAP onset, median (IQR) & $4(3-7)$ & $10(6-3)$ & $0.03 *$ & 1.07 & $1-1.14$ \\
\hline SAPS II on the day of VAP onset, median (IQR) & $39(31-49)$ & $48(43-60)$ & 0.80 & 0.99 & $0.97-1.02$ \\
\hline Trauma, n (\%) & 34 (34.7) & $15(17.6)$ & 0.36 & 0.74 & $0.39-1.40$ \\
\hline Malignity, n (\%) & $3(3.1)$ & $13(15.3)$ & 0.11 & 1.73 & $0.88-3.39$ \\
\hline Blood transfusion, n (\%) & $74(75.5)$ & $78(91.8)$ & 0.11 & 2.10 & $0.83-5.33$ \\
\hline Hemodialysis/CRRT, n (\%) & $26(26.5)$ & $51(60)$ & 0.2 & 0.7 & $0.4-1.21$ \\
\hline Acinetobacter baumannii, n (\%) & $38(38.8)$ & $52(61.2)$ & $0.01 *$ & 1.82 & $1.12-2.96$ \\
\hline
\end{tabular}

were compared to determine the predictors of mortality. Demographic characteristics including age and sex, APACHE II, SOFA and SAPS II scores at ICU admission, length of ICU stay, the median duration of mechanical ventilation prior to VAP onset were not statistically different between two groups. The proportion of patients with early and late-onset VAP were similar in both survivor and non-survivor groups $(p=0.41)$. Among underlying diseases, the history of malignity was found to be at significantly higher rates in non-survivor group ( $p=0.003,0 R: 5.71,95 \%$ $\mathrm{Cl}$ 1.57-20.81). In terms of invasive procedures in ICU, the rates of blood transfusion and hemodialysis/continuous renal replacement therapy (CRRT) were more frequently applied in non-survivor group ( $p=0.03$, OR:3.61, 95\% Cl:1.46-8.88, $p<0.001$, OR:4.1, 95\% Cl:2.22-7.75) Although APACHE II, SOFA and SAPS II scores at admission were not statistically different between each group, they were found to be higher in non-survivors on the day of VAP onset. When comparing survivor and non-survivors in terms of microorganisms causing VAP, only Acinetobacter baumannii isolates were found to be at a significantly higher rates in non-survivor group $(p=0.01$, OR:1.82, 95\% Cl:1.12-2.96). Pseudomonas aerugino- sa and Klebsiella pneumoniae infections were seen more commonly in non-survivor group, but the difference was not statistically significant. Variables that were found to be significant in univariate analysis were evaluated with Cox regression analysis to predict independent factors associated with the mortality of VAP. Only SOFA score on the day of VAP onset and Acinetobacter baumannii were found to be independently asociated with 30-day mortality. Results of univariate and multivariate analysis are shown in Tables 1 and 2.

In the univariate analysis, rate of patients hospitalized with trauma was seen significantly higher in survivor group ( $p=0.009$, OR:0.4, 95\% Cl:0.2-0.8). However, according to the Cox regression analysis, trauma was not found to be an independent factor for the survival of VAP patients $(p=0.36, O R: 0.74$, 95\% Cl:0.39-1.40).

\section{DISCUSSION}

Although there are several guidelines for preventing ventilator-associated pneumonia, VAP continues to be one of the most common hospital-acquired infec- 
tions seen in ICUs. VAP rates vary between each hospital and each ICU and it has been stated at different rates in the studies. While the incidence of VAP was $10.8 / 1000$ ventilator days in a study conducted in Thailand, it was found as 50.87/1000 ventilator days in another study in Argentina ${ }^{(14,15)}$. In our country, it was found to be $16.1 / 1000$ ventilator days in the study of Engin et al, 8.98/1000 ventilator days in the study of Erbay et al, and 23.3 in the study of Uslu et al. ${ }^{(16-18)}$. In our study, the VIP incidence was found to be $12.5 / 1000$ ventilator days. Even in the same unit, VAP incidence may change over time. Therefore, it is important to follow the rates with surveillance regularly, and taking measures when there is an increase in VAP rates.

In the studies, Gram-negative bacteria have been reported as the most common isolates in VAP patients. Among these, the most common bacteria are Acinetobacter baumannii, Pseudomonas aeruginosa, and Klebsiella pneumoniae ${ }^{(19-28)}$. In our study, the microorganisms caused VAP were similar to those studies regarding their order of frequency (Figure 1). Acinetobacter baumannii strains were isolated in half of our patients and Pseudomonas aeruginosa strains were isolated in $20 \%$ of the patients.

One of the most important issue in nosocomial infections is the increasing antibiotic resistance over the years. Increasing rates of resistance against carbapenems, which were used in the treatment of MDR microorganisms, cause serious difficulties in the treatment of these patients and increase mortality and morbidity ${ }^{(29,30)}$. In our study, carbapenem resistance was observed in $42.6 \%$ of the patients. Acinetobacter spp. and Klebsiella pneumoniae isolates have been reported to develop resistance to most antibiotics at increasing rates over the years $(22,27,31)$. In the "European Antimicrobial Resistance Surveillance Network" (EARS-Net) 2017 report, carbapenem resistance among Klebsiella pneumoniae isolates were reported as $64.7 \%$ in Greece, $29.7 \%$ in Italy and $22.5 \%$ in Romania ${ }^{(32)}$. In Turkey, CandevirUlu et al. found carbapenem resistance to be $48 \%$ in the study conducted in ICUs in $2012^{(33)}$. Akgül et al. reported that the carbapenem resistance against K.pneumoniae strains increased to $66.9 \%$ in 2014 (34). In our study, although carbapenem resistance was
$54.4 \%$ against Acinetobacter strains which were responsible for half of the VAP cases, it was higher $(66.6 \%)$ against Klebsiella pneumoniae strains. As another finding, carbapenem resistance was found to be $40 \%$ in E.coli strains which were isolated in only 5 patients. With the widespread use of colistin for Gram-negative bacteria resistant to carbapenems, colistin resistance has also become a problem for these bacteria ${ }^{(35,36)}$. Koçak et al. found that $39.5 \%$ of 81 carbapenem-resistant K.pneumoniae isolates were also resistant to colistin ${ }^{(37)}$. In our study, 4 (25\%) of 16 carbapenem-resistant Klebsiella pneumoniae strains were also found to be resistant to colistin.

VAP has the highest mortality rates among nosocomial infections. In our study, the 30-day mortality rate was found to be higher (46.4\%). VAP mortality rates have been reported in studies varying between $14-70 \%{ }^{(38,39)}$. In a study conducted in China, the 30 -day mortality rate was $42.8 \%$, in a Brazilian study $35 \%$, in another study overall mortality in VAP patients was found to be 32.4 percent ${ }^{(40,6)}$. There are several factors affecting mortality in the patients with VAP. In our study, survivor and non-survivors were compared to evaluate the risk factors affecting 30-day mortality. Although there are several studies showing that older age has negative impact on survival, in our study no statistical difference was observed between two groups in terms of their mean ages. When the underlying diseases were evaluated, the rate of malignancy was found to be significantly higher in the nonsurvivor group. In two studies conducted in Turkey, the history of coronary artery disease was found to be independently associated with mortality in VAP patients ${ }^{(28,41)}$. In a study conducted in Thailand, history of malignancy was found to be associated with mortality, similar to our study (19). Immunosuppression predisposes patients to infections by impairing the host defense. But et al. found that corticosteroid use and history of malignancy were found to be higher in non-survivor group, similar to our study ${ }^{(28)}$. Considering the effect of invasive procedures on mortality, blood transfusion and hemodialysis/CRRT were found to have a higher impact on mortality in the non-survivor group, but these variables lost their significance in multivariate analysis (Table 2). 
When considering the univariate analysis, the proportion of patients with a history of trauma was found to be significantly higher in the survivor group (Table 1). Similarly, In a study performed in 2010, trauma and nontrauma groups were compared in VAP patients, and mortality was found to be lower in trauma patients ${ }^{(42)}$. In our data, when comparing the patients with and without trauma, it was seen that patients hospitalized due to trauma were significantly younger, with relatively fewer underlying diseases and with lower scores both on admission and the day of VAP onset. The low mortality in trauma patients was attributed to these reasons.

APACHE II, SOFA and SAPS II scale scores at admission were not statistically different between each group, but when looking at scores at the time of VAP onset, it was seen that all scores of these scales were significantly higher in the non-survivor group (Table 1). Studies have shown that severity of illness is important for the prognosis after infections $(8,43,44)$. High scores in our study are compatible with the literature. According to the results of multivariate analysis, the SOFA scores at the time of VAP onset was independently associated with mortality. In a study carried out by Inchai et al, SOFA and SAPS II scores at the time of VAP onset were found to be associated with mortality ${ }^{(19)}$. In a study in China, SOFA scores were independently associated with mortality in VAP patients, and in another study, APACHE II scores at the time of VAP onset were found to be a poor indicator for prognosis ${ }^{(40,45)}$. In our study, only the SOFA scores at the time of VAP onset and Acinetobacter baumannii were found to be independent predictors of 30-day mortality in VAP patients (Table 2). Acinetobacter baumannii strains isolated in VAP patients have been shown in many studies to increase the mortality, and our results were compatible with the literature in this respect ${ }^{(46,47)}$.

The retrospective design and being a single-centre study are the major limitations of our study. Also our study did not investigate data about antimicrobial treatment, therefore we could not evaluate the effect of appropriateness of the antibiotherapy on mortality.

In conclusion, according to our results the most com- mon cause of VAP was Acinetobacter baumannii isolated in half of the patients. Carbapenem resistance, one of the most important treatment challenges, was seen in more than half of Acinetobacter baumannii and Klebsiella pneumoniae isolates. Our study also has shown that VAP is associated with high mortality as well as high SOFA score on the day of VAP onset and Acinetobacter baumannii infections with poor outcome.

Ethics Committee Approval: Approval was obtained from Bakirkoy Dr. Sadi Konuk Training and Research Hospital Clinical Research Ethics Committee (202-12 / 08.06.2020).

Conflict of Interest: none.

Funding: none

Informed Consent: It is a retrospective study.

\section{REFERENCES}

1. Čiginskienè A, Dambrauskienè A, Rello J, et al. Ventilator-Associated Pneumonia due to DrugResistant Acinetobacter baumannii: Risk Factors and Mortality Relation with Resistance Profiles, and Independent Predictors of In-Hospital Mortality. Medicina (Kaunas). 2019;55(2):49. https://doi.org/10.3390/medicina55020049

2. Ozgur E, Horasan E, Karaca K, et al. Ventilator-associated pneumonia due to extensive drug-resistant Acinetobacter baumannii: Risk factors, clinical features, and outcomes. Am J Infect Control. 2014;42(2):206-8. https://doi.org/10.1016/j.ajic.2013.09.003

3. Li YJ, Pan CZ, Fang CQ, et al. Pneumonia caused by extensive drug-resistant Acinetobacter baumannii among hospitalized patients: genetic relationships, risk factors and mortality. BMC Infect Dis. 2017;17(1):371. https://doi.org/10.1186/s12879-017-2471-0

4. Vazquez Guillamet $\mathrm{C}$, Kollef $\mathrm{MH}$. Acinetobacter Pneumonia: Improving Outcomes With Early Identification and Appropriate Therapy. Clin Infect Dis. 2018;67(9):1455-62. https://doi.org/10.1093/cid/ciy375

5. Kalil AC, Metersky ML, Klompas M, et al. Executive Summary: Management of Adults With Hospitalacquired and Ventilator-associated Pneumonia: 2016 Clinical Practice Guidelines by the Infectious Diseases Society of America and the American Thoracic Society. Clin Infect Dis. 2016;63(5):575-82. https://doi.org/10.1093/cid/ciw504

6. Huang $Y$, Jiao $Y$, Zhang J, et al. Microbial etiology and prognostic factors of ventilator- associated pneumonia: a multicenter retrospective study in Shanghai. Clin Infect Dis. 2018;67(suppl_2):146-52. https://doi.org/10.1093/cid/ciy686

7. Ding $C$, Zhang $Y$, Yang $Z$ et al. Incidence, temporal trend and factors associated with ventilator-associated pneumonia in mainland China: A systematic review and 
meta-analysis. BMC Infect Dis. 2017;17(1):468. https://doi.org/10.1186/s12879-017-2566-7

8. da Silveira F, Nedel WL, Cassol R et al. Acinetobacter etiology respiratory tract infections associated with mechanical ventilation: What impacts on the prognosis? A retrospective cohort study. J Crit Care. 2019;49: 124-8. https://doi.org/10.1016/j.jcrc.2018.10.034

9. Nseir S, Di Pompeo C, Pronnier P, et al. Nosocomial tracheobronchitis in mechanically ventilated patients: incidence, aetiology and outcome. Eur Respir J. 2002;20(6):1483-9. https://doi.org/10.1183/09031936.02.00012902

10. Torres A, Aznar R, Gatell JM, et al. Incidence, risk, and prognosis factors of nosocomial pneumonia in mechanically ventilated patients. Am Rev Respir Dis. 1990;142(3):523-8. https://doi.org/10.1164/ajrccm/142.3.523

11. Rello J, Ausina V, Ricart $M$, et al. Impact of previous antimicrobial therapy on the etiology and outcome of ventilator-associated pneumonia. Chest. 1993;104(4): 1230-5.

https://doi.org/10.1378/chest.104.4.1230

12. Nseir S, Di Pompeo C, Soubrier S, et al. Impact of ventilator-associated pneumonia on outcome in patients with COPD. Chest. 2005;128(3):1650-6.

https://doi.org/10.1378/chest.128.3.1650

13. European Centre for Disease Prevention and Control. European surveillance of healthcareassociated infections in intensive care units - HAI-Net ICU protocol, version 1.02. Stockholm: ECDC; 2015. Available from: https://www.ecdc.europa.eu/sites/default/files/ media/en/publications/Publications/healthcare-associated-infections-HAI-ICU-protocol.pdf

14. Thongpiyapoom S, Narong MN, Suwalak N, et al. Device-associated infections and patterns of antimicrobial resistance in a medical-surgical intensive care unit in a university hospital in Thailand. J Med Assoc Thai. 2004;87(7):819-24.

PMID: 15521239.

15. Rosenthal VD, Guzmán S, Crnich C. Device associated nosocomial infection rates in intensive care units of Argentina. Infect Control Hosp Epidemiol. 2004;25(3):251-5. https://doi.org/10.1086/502386

16. Ergin F, Kurt Azap Ö, Yapar G, et al. Başkent Üniversitesi Hastanesi'nde saptanan ventilatörle ilişkili pnömoniler: insidans, risk faktörleri, etken dağılımı ve antibiyotik direnç paternleri. Flora. 2004;9(2):119-24. Available from: http://www.floradergisi.org/getFileContent. aspx?op=html\&ref_id=106\&file_name=2004-9-2-119124.htm\&_pk=709c99b4-17fb-4d0c-868b-34a3504d8102

17. Erbay RH, Yalçın AN, Zencir M, et al. Costs and risk factors for ventilator-associated pneumonia in a Turkish university hospital's intensive care unit: a case-control study. BMC Pulm Med. 2004;4:3. https://doi.org/10.1186/1471-2466-4-3

18. Uslu $M$, Öztürk DB, Kuşçu $F$, et al. Yoğun Bakım Ünitesinde Yatan Hastalarda Ventilatörle İlişkili Pnömoni Gelişmesine Etki Eden Risk Faktörleri. Klimik Dergisi. 2010;23(3):83-8. Available from: https://klimikdergisi.org/content/files/sayilar/6/buyuk/83-8.pdf

19. Inchai J, Pothirat C, Liwsrisakun C, et al. Ventilator- associated pneumonia: epidemiology and prognostic indicators of 30-day mortality. Jpn J Infect Dis. 2015;68(3):181-6.

https://doi.org/10.7883/yoken.JJID.2014.282

20. Goel N, Chaudhary U, Aggarwal R, et al. Antibiotic sensitivity pattern of gram negative bacilli isolated from the lower respiratory tract of ventilated patients in the Intensive care unit. Indian J Crit Care Med. 2009;13(3): 148-51. https://doi.org/10.4103/0972-5229.58540

21. Palabıyık $O$, Öğütlü $A$, Toptaş Y. Yoğun bakım ünitesinde ventilatör ilişkili pnömoni ve etken mikroorganizmalar: iki yıllık retrospektif analiz. J Turk Soc Intens Care. 2016;14:80-5. https://doi.org/10.4274/tybdd.60490

22. Akın A, Esmaoğlu Çoruh A, Alp E, et al. Anestezi yoğun bakım ünitesinde beş yıl içerisinde gelişen nozokomiyal enfeksiyonlar ve antibiyotik direncinin değerlendirilmesi. Erciyes Med J 2011;33(1):7-16. Available from: https://www.journalagent.com/erciyesmedj/pdfs/EMJ_33_1_7_16.pdf

23. Tomak $Y$, Ertürk $A$, Şen $A$, et al. Anestezi yoğun bakım ünitesinde ventilatör ilişkili pnömoni hızları ve etken mikroorganizmaların dağılımı. ŞEEAH Tıp Bülteni. 2012;46(3):115-9. Available from: https://www.journalagent.com/sislietfaltip/pdfs/SETB_46_3_115_119.pdf

24. Göktaş U, Yaman G, Karahocagil MK, et al. Anestezi yoğun bakım ünitesinde hastane kaynaklı enfeksiyon etkenleri ve direnç profilinin değerlendirilmesi. J Turk Soc Intens Care. 2010;8(1):13-7. Available from: http:// cms.galenos.com.tr/Uploads/Article_4235/13-17.pdf

25. Ertürk $A$, Çopur Çiçek $A$, Köksal E, et al. Yoğun bakım ünitesinde yatan hastaların çeşitli klinik örneklerinden izole edilen mikroorganizmalar ve antibiyotik duyarlılıkları. ANKEM Derg 2012;26(1):1-9. https://doi.org/10.5222/ankem.2012.001

26. Ak O, Batirel A, Ozer S, et al. Nosocomial infections and risk factors in the intensive care unit of a teaching and research hospital: a prospective cohort study. Med Sci Monit. 2011;17(5):PH29-34. https://doi.org/10.12659/MSM.881750

27. Sesli Çetin E, Kaya S, Pakbaş I, et al. Yoğun bakım ünitelerinde yatan hastalardan izole edilen mikroorganizmalar ve antibiyotik duyarlılıkları. İnönü Üniversitesi Tıp Fakültesi Dergisi 2007;14:69-73. Available from: https://www.researchgate.net/profile/Selcuk_Kaya/ publication/266464194

28. But A, Yetkin MA, Kanyılmaz D, et al. Analysis of epidemiology and risk factors for mortality in ventilator-associated pneumonia attacks in intensive care unit patients. Turk J Med Sci. 2017;47:812-6. https://doi.org/10.3906/sag-1601-38

29. Centers for Disease Control and Prevention (CDC). Guidance for control of infections with carbapenemresistant or carbapenemase-producing Enterobacteriaceae in acute care facilities. MMWR Morb Mortal Wkly Rep. 2009;58:256-60. PMID: 19300408.

30. Schwaber MJ, Carmeli Y. Carbapenem-resistant Enterobacteriaceae: a potential threat. JAMA. 2008;300(24):2911-3. https://doi.org/10.1001/jama.2008.896

31. Senbayrak-Akcay S, Inan A, Cevan S, et al. Gramnegative bacilli causing infections in an intensive care unit of a tertiary care hospital in Istanbul, Turkey. J 
Infect Dev Ctries. 2014;8(5):597-604. https://doi.org/10.3855/jidc.4277

32. European Centre for Disease Prevention and Control (ECDC). Surveillance of antimicrobial resistance in Europe Annual report of the European Antimicrobial Resistance Surveillance Network (EARS-Net) 2017. Available from: https://www.ecdc.europa.eu/sites/ default/files/documents/AMR\%202017 Cover\%2BInner-web_v3.pdf

33. Candevir Ulu A, Kurtaran B, Inal AS, et al. Risk factors of carbapenem-resistant Klebsiella pneumoniae infection: a serious threat in ICUs. Med Sci Monit. 2015;21:219-24. https://doi.org/10.12659/MSM.892516

34. Akgul F, Bozkurt I, Sunbul M, et al. Risk factors and mortality in the carbapenem-resistant Klebsiella pneumoniae infection: case control study. Pathog Glob Health. 2016;110(7-8):321-5. https://doi.org/10.1080/20477724.2016.1254976

35. Rojas LJ, Salim M, Cober E, Richter SS, Perez F, Salata RA, et al. Colistin resistance in carbapenem-resistant Klebsiella pneumoniae: Laboratory detection and impact on mortality. Clin Infect Dis. 2017;64(6):711-8. https://doi.org/10.1093/cid/ciw805

36. Capone A, Giannella M, Fortini D, Giordano A, Meledandri M, Ballardini $M$, et al. High rate of colistin resistance among patients with carbapenem resistant Klebsiella pneumoniae infection accounts for an excess of mortality. Clin Microbiol Infect. 2013;19(1):E23E30.

https://doi.org/10.1111/1469-0691.12070

37. Koçak CÖ, Hazırolan G. Karbapeneme dirençli Klebsiella pneumoniae klinik izolatlarında kolistin direnci. Türk Mikrobiyoloji Cem Derg. 2019;49(1):17-23. https://doi.org/10.5222/TMCD.2019.017

38. Melsen WG, Rovers MM, Bonten MJ. Ventilatorassociated pneumonia and mortality: a systematic review ofobservational studies. Crit Care Med. 2009;37(10):2709-18. https://doi.org/10.1097/CCM.0b013e3181ab8655

39. Gvozdenovi'c L, Kolarovi'c J, Sarkanovi'c-Luki'c M, et al. Incidence and outcome of ventilator-associated pneumonia (our experience). Braz J Infect Dis.
2012;16(6):599-600.

https://doi.org/10.1016/j.bjid.2012.07.012

40. Feng DY, Zhou YQ, Zhou M, Zou XL, Wang YH, Zhang TT. Risk factors for mortality due to ventilator-associated pneumonia in a Chinese hospital: A Retrospective Study. Med Sci Monit. 2019;25:7660-5. https://doi.org/10.12659/MSM.916356

41. Ibrahim EH, Ward S, Sherman G, et al. A comparative analysis of patients with early-onset vs late-onset nosocomial pneumonia in the ICU setting. Chest. 2000;117(5):1434-42. https://doi.org/10.1378/chest.117.5.1434

42. Magret M, Amaya-Villar R, Garnacho J, et al. Ventilatorassociated pneumonia in trauma patients is associated with lower mortality: results from EU-VAP study. J Trauma. 2010;69(4):849-54. https://doi.org/10.1097/TA.0b013e3181e4d7be

43. Inchai J, Pothirat C, Bumroongkit C, et al. Prognostic factors associated with mortality of drug-resistant Acinetobacter baumannii ventilator-associated pneumonia. J Intensive Care. 2015;3:9. https://doi.org/10.1186/s40560-015-0077-4

44. Karakuzu Z, Iscimen $\mathrm{R}$, Akalin $\mathrm{H}$, et al. Prognostic risk factors in ventilator-associated pneumonia. Med Sci Monit. 2018;24:1321-8. https://doi.org/10.12659/MSM.905919

45. Huang KT, Teng CC, Fang WF, et al. An early predictor of the outcome of patients with ventilator-associated pneumonia. Chang Gung Med J. 2010;33(3):274-82. Available from: http://cgmj.cgu.edu.tw/3303/330306. pdf

46. Siempos II, Vardakas KZ, Kyriakopoulos CE, et al. Predictors of mortality in adult patients with ventilator-associated pneumonia: a meta-analysis. Shock. 2010;33(6):590-601. https://doi.org/10.1097/SHK.0b013e3181cc0418

47. Chittawatanarat K, Jaipakdee W, Chotirosniramit N, et al. Microbiology, resistance patterns, and risk factors of mortality in ventilator-associated bacterial pneumonia in a Northern Thai tertiary-care university based general surgical intensive care unit. Infect Drug Resist. 2014;7:203-10.

https://doi.org/10.2147/IDR.S67267 